\title{
Overreliance on China and dynamic balancing in the shift of global value chains in response to global pandemic COVID-19: an Australian and New Zealand perspective
}

\author{
Hongzhi Gao' ${ }^{1}$ Monica Ren ${ }^{2}$
}

Published online: 22 May 2020

(c) Springer Nature Limited 2020

The global coronavirus pandemic, also known as COVID-19, has hit every corner of the world. In Australia and New Zealand (AU \& NZ), travel bans, border closures, and the stay-at-home order have severely disrupted various industries including aviation, tourism, and international education. Virgin Australia, the second biggest airline in Australia, was forced into voluntary administration. World-famous Queenstown swung from the "most prosperous" town to the "most miserable" town in New Zealand during the pandemic. Universities in both countries are seeing themselves in a deep cash crisis from the shortfall of international student revenues, especially from China and other Asian countries (Table 1).

\section{Two competing views of the global value (supply) chain}

Any country participating in a global value chain will inevitably bear the brunt of a global pandemic disruption. There are generally two competing arguments on the supply sides of the global value chain; one promotes a further integration among members with a central supply from Asia (Gereffi 2014) and the other one is critical of the economic logic and rather promotes an ideological logic (Ahlstrom et al. 2020).

The favourable view of global integration predominantly focuses on the benefits of the scale, efficiency, and interdependence in the value chain. The alternative, critical view of global integration rises above the economic logic and anchors on ideological conflicts between countries (e.g. the USA is considered a free-market economy and China is generally perceived to be a state-controlled economy) and

Hongzhi Gao

hongzhi.gao@vuw.ac.nz

Monica Ren

monica.ren@mq.edu.au

1 Victoria University of Wellington, Wellington, New Zealand

2 Macquarie University, Sydney, Australia

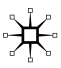




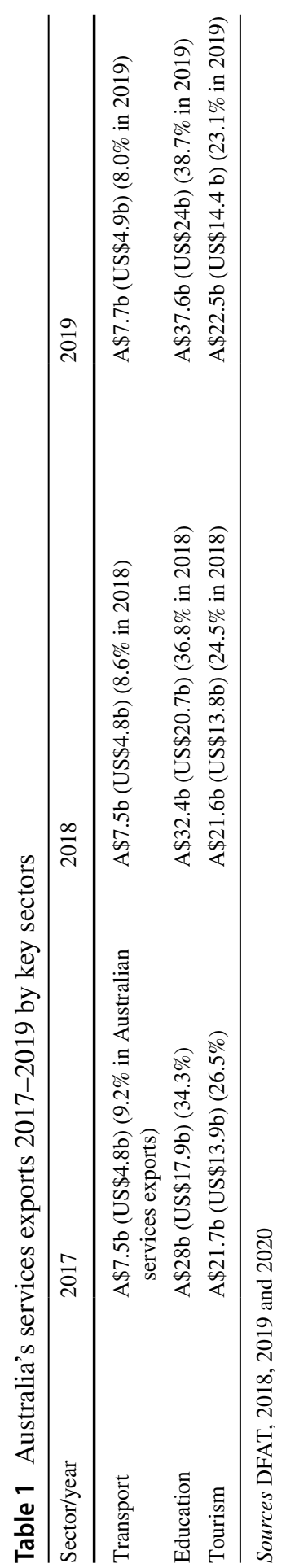


promotes common political and social values unifying members of the global value chain. The latter view appears to dominate the discussion among policy-makers in Western countries after the pandemic outbreak. The governments including Japan, the USA, and the EU have started to introduce or at least discuss the stimulation policies to induce firms to retreat their value chains from China (Bermingham et al. 2020).

\section{Overdependence on China}

At the centre of the debate about any major shift of global value chains triggered by the COVID-19 pandemic appears to be the position of China. Although a firm can get the scale and efficiency as well as access to the world's most populated market when building their value/supply chain around China, this focus has quickly become a disadvantage in a macro-environment disruption during the current pandemic.

In $\mathrm{AU} \& \mathrm{NZ}$, a popular view before the pandemic is that the two countries can prosper through developing their strategic positions at two ends of the China-centred value chain: supplies of natural resources and agricultural produce at the lower end and offerings of branded food products and highly profitable education and tourism services at the higher end. The resource and energy industries have brought in hundreds of billions AU dollars' in export earnings a year (predominantly from China) (DFAT 2020). China topped the sourcing countries for international students in Australia by a $28 \%$ share (in some universities, it was as high as $70 \%$ ).

The COVID-19 pandemic has suddenly put a pause, if not a full stop, to the internationalization of many of the above-mentioned industries in AU \& NZ. Exports of minerals, dairy, meat, wool, and wine, among many other agriculture and food products, have been largely stuck in the delay of freight services. The leaders in the tourism industry and tertiary education providers are scratching their heads and trying to formulate their response strategies to protect their financial bottom lines from a global pandemic.

\section{Shift of the global value chain}

Although the immediate focus of AU \& NZ governments has been primarily placed upon jobs and business survival, there is an increasing call for reducing overdependence on China in response to the pandemic.

Some AU and NZ companies' performance was impressive during the pandemic. For example, ResMed-led manufactures from Australia boosted ventilators from 2200 to 7500 units from March to April 2020. Fisher \& Paykel Healthcare (a New Zealand company) similarly ramped up productions for respiratory devices in Auckland and Mexico. However, a close examination of the supply of medical devices and pharmaceutical materials desperately needed in fighting against the virus by the world only found that this value chain was still heavily reliant on China.

One critical, strategic implication of the pandemic for AU \& NZ firms is how to achieve resilience for their global value chains. Key drivers to a resilient value 
(or supply) chain are agility, diversification, and interchangeability. The pandemic presses firms to re-evaluate their value chains, especially in knowledge-intensive and medical industries, and seek collaboration from the companies who they deem to be like-minded from an ideological perspective, and face a lesser political pressure from a state-controlled economy like China. There would be more AU\&NZ firms who renew their focus on the USA, the UK, and other Western and emerging markets (such as India and ASEAN countries) as a natural response in building a resilient global value chain after the pandemic. This renewed focus is largely due to their risk avoidance (there are more political risks to sell to or source from China) and the increase of perceived importance of an institutional proximity in the global value chain. For example, Australian firm AVH has recently announced its intention to transfer listing from ASX to the US stock market to align with their strategic resources in the US market.

\section{Achieving resilience by dynamic balancing}

While economic integration with institutionally aligned countries in terms of FDI, $\mathrm{R} \& \mathrm{D}$, and manufacturing emerges from the debate during the pandemic (Bermingham et al. 2020), this does not necessarily mean that AU \& NZ firms should cut ties with China. In the foreseeable future, China will still likely hold the number one spot for the exports of primary products and food products from AU \& NZ. In our view, it would be probably more realistic and strategically savvy if firms could start to embrace a "dynamic balancing" approach (Gao et al. 2018).

Key to dynamic balancing is building at least two interchangeable, complementary value chains that do not solely rely on China. Primary industry exporters should consider a number of other emerging markets (e.g. India, Indonesia, ASEAN, and South American countries) to reduce their overreliance on China. Manufacturers in the high-tech areas or the high-end of the global value chain should start to build at least a small production base in home country or nearshore where there is a lesser likelihood of an international political disruption during the pandemic.

Second, it is time to reengage a powerful intermediary who has international connections, capabilities, and resources to build a supply base that diversifies from China. According to a confidential industry source, his trading company (as an intermediary) has recently diluted their original $100 \%$ China sourcing strategy and moved towards Saudi Arabia and South Korea for new chemical supplies to respond to the requirements from clients in the US and other markets. A SME exporter's strategy of leveraging the capabilities of large intermediaries (e.g. those sourcing for FPH or RedMed) would likely achieve the breadth and flexibility in global supply chains and enable the exporter to balance markets and supplies effectively and efficiently.

Last but not least, enhancing corporate guanxi networks (Gao et al. 2018) is still important in diversifying from China. Supporting each other through a difficult time is considered an opportunity to lift the guanxi relationship to a higher level. This does not mean that the AU or NZ business partners should hide their diversification strategy from their guanxi partners; rather the opposite, dancing with multiple 
partners in different guanxi networks is exactly what the intricacies and dynamics of guanxi balancing are all about. When things get tougher, the more adaptive players who strategically span different guanxi networks in exporting or sourcing would most likely survive and prosper.

\section{References}

Ahlstrom, D., Arregle, J. L., Hitt, M. A., Qian, G., Ma, X., \& Faems, D. (2020). Managing technological, sociopolitical, and institutional change in the new normal. Journal of Management Studies, 57(3), 411-437.

Bermingham, F., Magnier, M., \& Leng, S. (2020). Coronavirus: China faces fight to hang onto foreign manufacturers as US, Japan, EU make COVID-19 exit plans. South China Morning Post. Retrieved from https://www.scmp.com/economy/china-economy/article/3081415/coronavirus-china-faces -fight-hang-foreign-manufacturers-us.

DFAT. (2020). Trade and investment at a glance 2020. Barton: Department of Foreign Affairs and Trade Australian Governement.

Gao, H., Ren, M., \& Miao, Q. (2018). Toward a yin-yang balancing perspective of relational (guanxi) gatekeeping in international exchange relationships in China. Journal of International Marketing, $26(2), 22-42$.

Gereffi, G. (2014). Global value chains in a post-Washington Consensus world. Review of International Political Economy, 21(1), 9-37.

Publisher's Note Springer Nature remains neutral with regard to jurisdictional claims in published maps and institutional affiliations. 